Proceedings of the 24th International Symposium "The Environment and the Industry" (E-SIMI 2021), 24 September 2021, online event

\title{
An overview of methods used for quantification of heavy metal contents in vegetal samples
}

\author{
GINA VASILE SCAETEANU ${ }^{1}$, ROXANA MARIA MADJAR $^{1 *}$, ANDREI MOT $^{1,2}$ \\ ${ }^{1}$ University of Agronomic Sciences and Veterinary Medicine, Faculty of Agriculture, 59 Blvd. Marasti, 011464, \\ Bucharest, Romania; \\ ${ }^{2}$ Research Center for Studies of Food and Agricultural Products Quality, 59 Blvd. Marasti, 011464, Bucharest, \\ Romania. \\ *Corresponding author: rmadjar@gmail.com
}

$\begin{array}{lll}\text { Received: } & \text { Accepted: } & \text { Published: } \\ \text { 20.07.2021 } & 17.09 .2021 & 17.12 .2021\end{array}$

\begin{abstract}
Continuous monitoring of heavy metals content in vegetal products is a priority for food control and a risk assessment strategy for human health. Having in view the importance of heavy metals surveillance, the aim of this paper is to identify, on the basis of literature data, the most suitable procedures and techniques used for accurate determination of them in vegetal samples. In most cases, quantification of heavy metals in vegetal matrix is preceded by digestion performed through different protocols chosen carefully because this is a critical step for obtaining accurate results. Among most used techniques for heavy metals' assessment from vegetal products reported by literature it worth to be mentioned: atomic absorption spectrometry (AAS), inductively coupled plasma-mass spectrometry (ICP-MS), inductively coupled plasma - optical emission spectrometry (ICP-OES), X-ray fluorescence $(X R F)$, neutron activation analysis (NAA), anodic stripping voltammetry (ASV).
\end{abstract}

Keywords: accumulation, analytical methods, heavy metals, quantification, vegetal samples.

\section{INTRODUCTION}

Definition of the term "heavy metals" was widely discussed during time and there are several opinions regarding this issue. Chemical elements defined as "heavy metals" has density greater than $5 \mathrm{~g} / \mathrm{cm}^{3}$ and corresponding elements commonly found in our everyday life are: titanium, vanadium, chromium, manganese, iron, cobalt, nickel, copper, zinc, arsenic, molybdenum, silver, cadmium, tin, platinum, gold, mercury, lead [1]. As concerning implications in environmental and biological contexts, "heavy metals" are metallic chemical elements and metalloids that are associated with pollution and harmful effects on environment, including humans [1].

In this paper, the term "heavy metals" is used from environmental point of view and is related to their effects on human health.

Heavy metals environmental presence is mainly a result of human activities associated with agriculture (use of fertilizers and pesticides), industrial purposes and in some situations is a consequence of natural causes as volcanic activity, soil erosion, geological weathering [1].

Unlike the nitrogen and potassium fertilizers, phosphate fertilizer application is a significant contributor of trace element presence, being a common impurity, especially for arsenic, cadmium and lead accumulation in cropland soils and therefore in plants. 
According to literature, most phosphorus fertilizers contain arsenic, cadmium and lead at levels below $20 \mathrm{mg} / \mathrm{kg}$ [2]. Other metals identified in phosphate rocks are chromium, mercury, nickel, vanadium at variable levels related to the source of phosphate [3].

Lately, atmospheric deposition of metals has been considered as an important source of metals (arsenic, cadmium, lead) entering soils and there are many studies related with this subject [4-6]. Also, elevated levels of heavy metals in plants were reported for cases where the irrigation was performed with wastewater [7].

Wong et al. reported the presence of heavy metals in Chinese herbal medicinal plants and related it with contamination that occurred during air-drying and preservation practices [8].

Lead, cadmium, chromium, mercury and arsenic are heavy metals of particular concern due to their harmful effects on human health because of their tendency to accumulate in tissues and to be stored in organs (liver, kidney).

In Regulation (EC) No 1881/2006 the EU Commission has set maximum levels (MLs) for lead, cadmium, mercury and tin in different foodstuffs (meats, fish, crustaceans, molluscs, cephalopods, cereal, legumes, pulses, fruit and fruit juices, fats, wines, milk, canned food and beverages).

Having in view that this paper presents the methods used for quantification of heavy metals in vegetal products, in Table 1 are gathered maximum levels for lead and cadmium in vegetal products and provisional tolerable weekly intake (PTWI) for these two metals. For mercury and tin the sources are represented by fish, fishery products and canned products, respectively.

Table 1. Maximum admitted levels for lead and cadmium in vegetal products and provisional tolerable weekly intake (PTWI) [9]

\begin{tabular}{|c|c|c|}
\hline $\begin{array}{l}\text { Heavy } \\
\text { metal }\end{array}$ & Foodstuffs & $\begin{array}{c}\text { Maximum level } \\
\text { (mg/kg fresh weight) }\end{array}$ \\
\hline \multirow{5}{*}{$\begin{array}{c}\text { Lead } \\
(\mathrm{Pb})\end{array}$} & Cereals, legumes and pulses & 0.20 \\
\hline & $\begin{array}{l}\text { Vegetables, excluding brassica vegetables, leaf vegetables, } \\
\text { fresh herbs and fungi. For potatoes the maximum level } \\
\text { applies to peeled potatoes. }\end{array}$ & 0.10 \\
\hline & Brassica vegetables, leaf vegetables and cultivated fungi & 0.30 \\
\hline & Fruit, excluding berries and small fruit & 0.10 \\
\hline & Berries and small fruit & 0.20 \\
\hline \multicolumn{2}{|c|}{ PTWI for lead, $\mathrm{mg} / \mathrm{kg}$ body weight } & 0.025 \\
\hline \multirow{6}{*}{$\begin{array}{l}\text { Cadmium } \\
\qquad(\mathrm{Cd})\end{array}$} & Cereals excluding bran, germ, wheat and rice & 0.10 \\
\hline & Bran, germ, wheat and rice & 0.20 \\
\hline & Soybeans & 0.20 \\
\hline & $\begin{array}{l}\text { Vegetables and fruit, excluding leaf vegetables, fresh } \\
\text { herbs, fungi, stem vegetables, pine nuts, root vegetables } \\
\text { and potatoes }\end{array}$ & 0.050 \\
\hline & Leaf vegetables, fresh herbs, cultivated fungi and celeriac & 0.20 \\
\hline & $\begin{array}{l}\text { Stem vegetables, root vegetables and potatoes, excluding } \\
\text { celeriac. For potatoes the maximum level applies to peeled } \\
\text { potatoes. }\end{array}$ & 0.10 \\
\hline \multicolumn{2}{|c|}{ PTWI for cadmium, $\mathrm{mg} / \mathrm{kg}$ body weight } & 0.007 \\
\hline
\end{tabular}

\section{Heavy metals accumulation in vegetal products}

The accumulation of heavy metals in plants is discussed in literature from two perspectives:

(i) elevated levels of heavy metals produce a wide variety of physiological changes in plants (inhibit the ability of the plant to synthesize chlorophyll, high oxidative stress, suppression of plant growth) [10] and modification of biochemical parameters (increase of sugar, phenol and ascorbic acid contents, decline of protein soluble levels) [7];

(ii) related to negative effects on consumers' health (chronic diseases, disturbances at central nervous system level, renal dysfunctions). 
The uptake of metals from soil depends on different factors such as their soluble content in soil, soil physical-chemical properties. The accumulation of metals varies greatly both between cultivars and varieties and is influenced by soil condition, environment and weather [11]. Also, uptake, transfer and accumulation of heavy metals vary with growth. There are studies that evidence higher concentrations of heavy metals in roots in comparison with other plant tissues stage [12].

A study conducted by Singh and his team investigated the accumulation of heavy metals from polluted soils in different vegetal products [13]. The results indicated that highest average lead content was found in leaves, followed by stem, roots and fruits. For cadmium and nickel, the highest levels were identified in roots and the lowest in fruits.

Similarly, for nickel were found high concentrations in root vegetables (parsley, potato), followed by fruiting vegetables (tomato, green bean, cucumber) collected from old mining areas [14].

Another study demonstrated that arsenic, lead and cadmium werehighly enriched in leafy vegetables and barely accumulated in fruit vegetables, all grown in contaminated soils [15]. The levels of cadmium in leafy vegetables were three times higher than those in non-leafy vegetables. Arsenic level reported by Gebeyehu and Bayissa in cabbage is three times higher than found in tomato [16].

The researches carried out to find the most suitable species for growing in cadmium contaminated soils revealed that the accumulation tendency follows the order: leafy vegetables $>$ solanaceous vegetables $>$ kale vegetables $>$ root vegetables $>$ melon vegetables $>$ legumes [17].

The ability of leafy vegetables to uptake and accumulate arsenic, cadmium and lead has been proven by Zhou et al. who reported the following variation for concentration: leafy vegetables>stalk vegetables>root vegetables [11].

\section{Methods for heavy metals quantification in vegetal products}

Usually for heavy metals assessment from vegetal samples, there are two steps to be followed by analyst: sample digestion (a) and quantification (b) using a suitable analytical technique chosen according to metal characteristics and its concentration in the analyzed sample.

a) For digestion different methods are used as calcination, microwave digestion in acidic medium, digestion with acids under heating, digestion with mixtures of concentrated acids. The selection of an appropriate digestion method ensures the correct determination of metals and it has been proven that certain digestion procedures impact the determination of metals. Accordingly, selection of the digestion method is a critical step for obtaining accurate results.

For instance, Gong and co-workers demonstrated that dry ashing is recommended for zinc and iron determination by flame atomic absorption spectrometry (FAAS), meanwhile for copper is more suitable the digestion with aqua regia- $\mathrm{HClO}_{4}$ mixture [18]. Also, for lead dry ashing method or mixed acid digestion could be used efficiently.

Other study reports an improved wet digestion method based on using of $\mathrm{H}_{2} \mathrm{O}_{2}$, concentrated $\mathrm{HNO}_{3}$ followed by heating at $100^{\circ} \mathrm{C}$ for iron, manganese, zinc and copper determination by FAAS from leaves of lucerne (Medicago sativa L.) [19].

Moreover, evaluation of three acid digestion methods ((a) $\mathrm{HNO}_{3}-\mathrm{HClO}_{4}, 2: 1$; (b) $\mathrm{HNO}_{3}$; (c) $\mathrm{HNO}_{3-}$ $\mathrm{HCl}, 1: 3$ ) for heavy metals from herbs by means of FAAS evidenced that the most efficient method that provides highest recovery for all investigated metals was method (c) [20].

Microwave assisted digestion in closed vessels is used frequently because it assures rapid dissolution of the sample matrix, needs small volumes of oxidizing reagents and prevents losses by volatilization of certain components [21].

b) Quantitative determination of metals is achieved mainly using atomic absorption spectrometry (AAS), inductively coupled plasma-mass spectrometry (ICP-MS), and inductively coupled plasma optical emission spectrometry (ICP-OES).

Among atomic absorption spectrometry techniques, flame atomic absorption spectrometry (FAAS) is widely used for metal determination from vegetal samples due to simplicity and because allows to quantify a lot of metals (cobalt, chromium, cadmium, copper, iron, manganese, nickel, lead, zinc), even at trace levels. 
Electrothermal atomic absorption spectrometry (ETAAS) requires higher atomization temperatures and supposes use of graphite furnace. The advantage of this technique is the small volume of sample $(20-50 \mu \mathrm{L})$ needed for analysis and very good detection limits [22].

Analysis of volatile elements (arsenic, antimony) by ETAAS needs use of chemical modifiers which stabilize the analyte which otherwise evaporates at temperatures higher than $400^{\circ} \mathrm{C}$ [23].

Chemical vapor generation in conjunction with atomic absorption spectroscopy is one of the most powerful tools for the achievement of trace elements in different matrices and includes hydride generation atomic absorption spectroscopy (HGAAS) and cold vapor atomic absorption spectroscopy (CVAAS).

HGAAS is used for hydride forming metals (selenium, arsenic, tin, lead), meanwhile CVAAS is the primary technique for mercury analysis from different samples.

Table 2. Overview of procedures used for heavy metals determination by AAS technique

\begin{tabular}{|c|c|c|c|c|}
\hline Sample & Metals & Digestion & $\begin{array}{c}\text { Analytical } \\
\text { technique }\end{array}$ & Reference \\
\hline $\begin{array}{l}\text { apple, orange, } \\
\text { grapes }\end{array}$ & $\begin{array}{l}\mathrm{Cd}, \mathrm{Cr} \\
\mathrm{Cu}, \mathrm{Pb} \\
\mathrm{Ni}\end{array}$ & $\begin{array}{l}5 \mathrm{~g} \text { sample dried at } 105^{\circ} \mathrm{C} \text { for } 16 \text { hours; } \\
\text { dry-ashing at } 540^{\circ} \mathrm{C} \text { for } 8-12 \text { hours; ash is } \\
\text { treated with } 1 \mathrm{~mL} \mathrm{HCl} 36 \%\end{array}$ & FAAS & [24] \\
\hline $\begin{array}{l}\text { fruits, } \\
\text { vegetables }\end{array}$ & $\mathrm{Cd}, \mathrm{Pb}$ & $\begin{array}{l}\text { samples are dried at } 105^{\circ} \mathrm{C} \text { and calcinated } \\
\text { at } 450^{\circ} \mathrm{C} \text {; residue was treated with } 5 \mathrm{~mL} \\
\mathrm{HNO}_{3} 65 \% \text { and heated on a sand bath at } \\
150^{\circ} \mathrm{C}\end{array}$ & FAAS & {$[25]$} \\
\hline $\begin{array}{l}\text { leafy and fruit } \\
\text { vegetables }\end{array}$ & $\begin{array}{l}\mathrm{Pb}, \mathrm{Cd} \\
\mathrm{Fe}, \mathrm{Zn} \\
\mathrm{Cu}\end{array}$ & $\begin{array}{l}10 \mathrm{~g} \text { sample }+10 \mathrm{~mL} \mathrm{HNO}_{3} \text { conc., } \\
\text { digestion at } 90^{\circ} \mathrm{C} \text { for } 45 \text { minutes and at } \\
130^{\circ} \mathrm{C} \text { for } 3 \text { hours }\end{array}$ & FAAS & [26] \\
\hline $\begin{array}{l}\text { leafy, fruit and } \\
\text { root } \\
\text { vegetables }\end{array}$ & $\begin{array}{l}\mathrm{Mn}, \mathrm{Fe} \\
\mathrm{Cu}, \mathrm{Zn} \\
\mathrm{Pb}, \mathrm{Cd}\end{array}$ & $\begin{array}{l}1 \mathrm{~g} \text { dry sample }+15 \mathrm{~mL} \text { triacid mixture } \\
\left(\mathrm{HNO}_{3} 70 \%, \mathrm{HClO}_{4} 65 \%, \mathrm{H}_{2} \mathrm{SO}_{4} 70 \%\right. \\
5: 1: 1)+ \text { digestion at } 80^{\circ} \mathrm{C}\end{array}$ & FAAS & [27] \\
\hline $\begin{array}{l}\text { leafy, fruit and } \\
\text { root } \\
\text { vegetables }\end{array}$ & $\begin{array}{l}\mathrm{Fe}, \mathrm{Mn} \\
\mathrm{Zn}, \mathrm{Cu} \\
\mathrm{Ni}, \mathrm{Cd} \\
\mathrm{Pb}\end{array}$ & $\begin{array}{l}\text { ash digestion; resulted residue was treated } \\
\text { with } \mathrm{HNO}_{3}\end{array}$ & FAAS & [28] \\
\hline $\begin{array}{l}\text { legumes, leafy } \\
\text { vegetables, } \\
\text { stems, roots, } \\
\text { fruits }\end{array}$ & $\begin{array}{l}\mathrm{Fe}, \quad \mathrm{Mn}, \\
\mathrm{Cu}, \mathrm{Zn}, \\
\mathrm{Pb}, \mathrm{Cd}, \\
\mathrm{Hg}\end{array}$ & $\begin{array}{l}\text { drying at } 100^{\circ} \mathrm{C} \text {, grinding } 1 \text { g dry sample }+ \\
15 \mathrm{~mL} \text { triacid mixture }\left(\mathrm{HNO}_{3} 65 \% \text {, }\right. \\
\left.\mathrm{HClO}_{4} 65 \%, \mathrm{H}_{2} \mathrm{SO}_{4} 70 \%, 5: 1: 1\right)+ \\
\text { digestion at } 80^{\circ} \mathrm{C}\end{array}$ & $\begin{array}{l}\text { ETAAS } \\
\text { HGAAS }\end{array}$ & [29] \\
\hline $\begin{array}{l}\text { lettuce, } \\
\text { raddish, } \\
\text { carrots }\end{array}$ & $\begin{array}{l}\mathrm{Fe}, \mathrm{Cu} \\
\mathrm{Cr}, \mathrm{Zn}\end{array}$ & $\begin{array}{l}\text { plant samples are dried at } 60^{\circ} \mathrm{C} \text {; digestion } \\
\text { with concentrated acids mixture }(4 \mathrm{~mL} \\
\left.\mathrm{HClO}_{4}+25 \mathrm{~mL} \mathrm{HNO}_{3}+2 \mathrm{~mL} \mathrm{H}_{2} \mathrm{SO}_{4}\right) \text {, } \\
\text { then is added } 1 \mathrm{~mL} \mathrm{H}_{2} \mathrm{O}_{2} 60 \% \text { and heated } \\
\text { at } 100^{\circ} \mathrm{C} \text { for } 2 \text { hours on a hot plate }\end{array}$ & FAAS & [30] \\
\hline salad, spinach & $\begin{array}{l}\mathrm{Cd}, \quad \mathrm{Cu}, \\
\mathrm{Pb}, \mathrm{Zn}\end{array}$ & $\begin{array}{l}\text { ashing at } 500^{\circ} \mathrm{C} \text { for } 4 \text { hours } \\
\text { digestion with } \mathrm{HNO}_{3}: \mathrm{H}_{2} \mathrm{O}_{2}=2: 1\end{array}$ & FAAS & [31] \\
\hline $\begin{array}{l}\text { spices and } \\
\text { herbs }\end{array}$ & $\mathrm{Hg}$ & $\begin{array}{l}\text { microwave assisted digestion with } \mathrm{HNO}_{3} \\
\text { conc. and } \mathrm{H}_{2} \mathrm{O}_{2} \text {; oxidative conversion of } \\
\text { all } \mathrm{Hg} \text { species to inorganic } \mathrm{Hg} \text { is ensured } \\
\text { by addition of } \mathrm{KMnO}_{4}\end{array}$ & CVAAS & [32] \\
\hline vegetables & $\begin{array}{l}\mathrm{Ni}, \mathrm{Zn}, \\
\mathrm{Cu}\end{array}$ & $\begin{array}{l}\text { sample is oven-dried at } 105^{\circ} \mathrm{C} \text { for } 24 \\
\text { hours; } 3 \mathrm{~g} \text { dried sample dry-ashed } 3 \text { hours } \\
\text { at } 450^{\circ} \mathrm{C} \text {; ash is treated with } 10 \mathrm{~mL} \mathrm{HNO}_{3} \\
\text { conc. }\end{array}$ & FAAS & [33] \\
\hline
\end{tabular}




\begin{tabular}{|c|c|c|c|c|}
\hline vegetables & $\begin{array}{l}\mathrm{Cd}, \mathrm{Pb} \\
\mathrm{Ni}, \mathrm{Co} \\
\mathrm{Cr}\end{array}$ & $\begin{array}{l}\text { drying at } 65^{\circ} \mathrm{C} ; 1 \mathrm{~g} \text { sample was digested in } \\
\text { Pyrex tubes with } \mathrm{HNO}_{3}: \mathrm{HClO}_{4}=3: 1\end{array}$ & FAAS & [34] \\
\hline vegetables & $\begin{array}{l}\mathrm{As}, \mathrm{Cd}, \\
\mathrm{Pb}\end{array}$ & $\begin{array}{l}5-10 \text { g sample digested with } 10 \text { mL } \mathrm{HNO}_{3} \\
\text { conc. and heated at la } 120^{\circ} \mathrm{C} \text {; periodically } \\
\text { was added } 1 \mathrm{~mL} \mathrm{H}_{2} \mathrm{O}_{2} 30 \% \text { until digestion } \\
\text { was complete }\end{array}$ & GFAAS & [35] \\
\hline vegetables & $\begin{array}{l}\mathrm{Cu}, \mathrm{Zn}, \\
\mathrm{Pb}, \mathrm{Cd}\end{array}$ & $\begin{array}{l}10 \mathrm{~g} \text { sample is dried at } 105^{\circ} \mathrm{C} \text {, then is } \\
\text { calcinated at } 450^{\circ} \mathrm{C} \text {; the ash is treated with } \\
5 \mathrm{~mL} \mathrm{HClO}_{4} \text { and } 10 \mathrm{~mL} \mathrm{HNO}_{3}\end{array}$ & $\begin{array}{l}\text { FAAS }(\mathrm{Cu}, \\
\mathrm{Zn}) \\
\text { GFAAS } \\
(\mathrm{Cd}, \mathrm{Pb})\end{array}$ & [36] \\
\hline
\end{tabular}

Inductively coupled plasma-mass spectrometry (ICP-MS) is a technique characterized by high precision and accuracy and is used for multielemental analysis at trace levels in various liquid samples. Therefore, solid samples must be digested before analysis. Digestion procedures require $\mathrm{HNO}_{3}$ or $\mathrm{HNO}_{3}$ and $\mathrm{H}_{2} \mathrm{O}_{2}$ as is presented in Table 3.

The sample is atomized and ionized in argon plasma and the resulted ions are separated by a mass analyzer according to their mass-charge ratio $(\mathrm{m} / \mathrm{z})$ and then are measured at the detector [37].

Table 3. Overview of procedures used for heavy metals determination by ICP-MS technique

\begin{tabular}{|c|c|c|c|}
\hline Sample & Metals & Digestion & Reference \\
\hline apple, carrots & $\mathrm{Cd}, \mathrm{Pb}, \mathrm{Cu}, \mathrm{Zn}$ & $\begin{array}{l}\text { digestion at } 200^{\circ} \mathrm{C} \text { with } 8 \mathrm{~mL} \mathrm{HNO}_{3} \text { and } 2 \\
\mathrm{~mL} \mathrm{H}_{2} \mathrm{O}_{2}\end{array}$ & [38] \\
\hline $\begin{array}{l}\text { corn, mint, } \\
\text { eggplant, pepper, } \\
\text { tomato }\end{array}$ & $\begin{array}{l}\mathrm{Cd}, \mathrm{Co}, \mathrm{Cr}, \mathrm{Cu} \\
\mathrm{Mo}, \mathrm{Ni}, \mathrm{Pb}, \mathrm{Zn}\end{array}$ & $\begin{array}{l}0.5 \mathrm{~g} \text { sample digested with } \mathrm{HNO}_{3} \text { conc. and } \\
\text { the resulted residue treated with aqua regia }\end{array}$ & [39] \\
\hline fruits & $\begin{array}{l}\mathrm{As}, \mathrm{Cd}, \mathrm{Co}, \mathrm{Cr} \\
\mathrm{Cu}, \mathrm{Hg}, \mathrm{Ni}, \mathrm{Pb} \\
\mathrm{Sb}, \mathrm{Se}, \mathrm{Tl}, \mathrm{Zn}\end{array}$ & $\begin{array}{l}0.5 \mathrm{~g} \text { sample treated with } 15 \mathrm{~mL} \mathrm{HNO}_{3} \text { and } \\
5 \mathrm{~mL} \mathrm{H}_{2} \mathrm{O}_{2} \text {, left overnight; digestion } 2 \text { hours } \\
\text { at } 130^{\circ} \mathrm{C}\end{array}$ & [40] \\
\hline fruits, vegetables & $\begin{array}{l}\mathrm{Pb}, \mathrm{Cd}, \mathrm{Hg}, \mathrm{V} \\
\mathrm{Cr}\end{array}$ & $\begin{array}{l}1 \mathrm{~g} \text { sample was treated with } 5 \mathrm{~mL} \mathrm{HNO}_{3} \\
69 \% \text { and } 1 \mathrm{~mL} \quad \mathrm{H}_{2} \mathrm{O}_{2} \quad 30 \% \text {, microwave } \\
\text { digested }\end{array}$ & [41] \\
\hline $\begin{array}{l}\text { fruits, vegetables, } \\
\text { nuts }\end{array}$ & $\begin{array}{l}\mathrm{Co}, \mathrm{Cr}, \mathrm{Cu} \\
\mathrm{Mn}, \mathrm{Mo}, \mathrm{Ni}, \\
\mathrm{Sr}, \mathrm{Tl}, \mathrm{U}, \mathrm{V}\end{array}$ & $\begin{array}{l}2 \mathrm{~g} \text { sample is treated with } 6 \mathrm{~mL} \mathrm{HNO}_{3} 68 \% \\
\text { and } 2 \mathrm{~mL} \mathrm{H} \mathrm{H}_{2} \mathrm{O}_{2} 30 \% \text {; microwave assisted } \\
\text { digestion }\end{array}$ & [42] \\
\hline vegetables & $\mathrm{Pb}, \mathrm{Zn}, \mathrm{Cd}, \mathrm{Cu}$ & $\begin{array}{l}0.5 \mathrm{~g} \text { dried sample microwave digested with } \\
5 \mathrm{~mL} \mathrm{HNO}_{3} \text { conc., heated at } 100^{\circ} \mathrm{C} \text { for } 30 \\
\text { minutes; after cooling was added } 2 \mathrm{~mL} \mathrm{H}_{2} \mathrm{O}_{2} \\
\text { and microwave digested for other } 21 \\
\text { minutes }\end{array}$ & [43] \\
\hline safflower & $\begin{array}{l}\mathrm{As}, \mathrm{Cd}, \mathrm{Hg}, \mathrm{Pb}, \\
\mathrm{Co}, \mathrm{Cr}, \mathrm{Ni}\end{array}$ & $\begin{array}{l}0.20 \mathrm{~g} \text { of dried plant sample is digested with } \\
5 \mathrm{~mL} \text { mixture } \mathrm{HNO}_{3} \text { and } \mathrm{HClO}_{4}(20: 1) .\end{array}$ & [44] \\
\hline $\begin{array}{l}\text { vegetables (fruits, } \\
\text { leaves, tubers, } \\
\text { bulbs) }\end{array}$ & $\mathrm{As}, \mathrm{Cd}, \mathrm{Pb}$ & $\begin{array}{l}\text { microwave digestion with } \mathrm{HNO}_{3} 65 \% \text { and } \\
\mathrm{H}_{2} \mathrm{O}_{2} 30 \%\end{array}$ & [45] \\
\hline
\end{tabular}

Inductively coupled plasma - optical emission spectrometry (ICP-OES) is suitable for multielemental analysis and is used for fast and accurate determination of trace elements in various samples. This technique uses plasma created by argon gas for atomization and is characterized by high sensitivity, good reproducibility and low matrix effect. Samples introduced in plasma must be liquid, thus digestion of the sample is required prior injection into the instrument. In Table 4 are 
presented procedures collected from literature for heavy metals assessment using ICP-OES technique.

Table 4. Overview of procedures used for heavy metals determination by ICP-OES technique

\begin{tabular}{|c|c|c|c|}
\hline Sample & Metals & Digestion & Reference \\
\hline $\begin{array}{l}\text { cereals, pulses, } \\
\text { tuber, nuts, dried } \\
\text { fruit }\end{array}$ & $\mathrm{Cd}, \mathrm{Cr}, \mathrm{Cu}, \mathrm{Pb}$ & $\begin{array}{l}0.25 \mathrm{~g} \text { dried sample treated with } 5 \mathrm{~mL} \mathrm{HNO}_{3} \\
\text { conc.; after an hour was microwave digested }\end{array}$ & [46] \\
\hline endive & $\begin{array}{l}\mathrm{Cd}, \mathrm{Co}, \mathrm{Cr}, \mathrm{Cu} \\
\mathrm{Fe}, \mathrm{Mn}, \mathrm{Mo}, \mathrm{Ni} \\
\mathrm{Pb}, \mathrm{Zn}\end{array}$ & $\begin{array}{l}0.5 \mathrm{~g} \text { dried plant was microwave digested with } \\
2 \mathrm{~mL} \mathrm{HNO} 3 \text { conc. and } 2 \mathrm{~mL} \mathrm{H}_{2} \mathrm{O}_{2}\end{array}$ & [47] \\
\hline fruit juices & $\mathrm{Cr}, \mathrm{Cd}, \mathrm{Pb}$ & $\begin{array}{l}0.5 \mathrm{~mL} \text { sample is treated with } 5 \mathrm{~mL} \mathrm{HNO}_{3} \\
69.5 \%, 2 \mathrm{~mL} \mathrm{H}_{2} \mathrm{O}_{2} 35 \% \text { and heated in oven at } \\
200^{\circ} \mathrm{C} \text { for } 20 \text { minutes, close to dryness }\end{array}$ & [48] \\
\hline fruits & $\begin{array}{l}\text { As, } \mathrm{Cd}, \mathrm{Co}, \mathrm{Cr} \\
\mathrm{Cu}, \mathrm{Hg}, \mathrm{Ni}, \mathrm{Pb} \\
\mathrm{Sb}, \mathrm{Se}, \mathrm{Tl}, \mathrm{Zn}\end{array}$ & 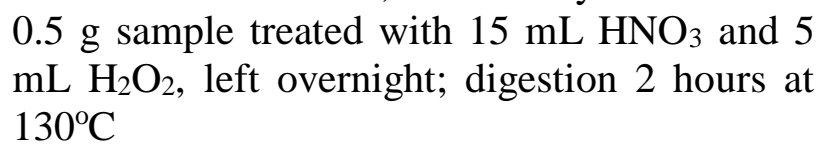 & {$[40]$} \\
\hline fruits & $\mathrm{As}, \mathrm{Cd}, \mathrm{Pb}$ & $\begin{array}{l}0.5 \mathrm{~g} \text { of dried and ground sample was } \\
\text { microwave digested using } 6 \mathrm{~mL} \mathrm{HNO}_{3} 65 \%, 2 \\
\mathrm{~mL} \mathrm{H}_{2} \mathrm{O}_{2} 30 \%\end{array}$ & [21] \\
\hline $\begin{array}{l}\text { lettuce, broad } \\
\text { bean }\end{array}$ & $\mathrm{Cd}, \mathrm{Pb}$ & $\begin{array}{l}\text { samples are dried at } 70^{\circ} \mathrm{C} \text {; digestion by wet } \\
\text { oxidation with } \mathrm{HNO}_{3} \text { conc. under pressure in a } \\
\text { microwave oven }\end{array}$ & [49] \\
\hline medicinal herbs & $\begin{array}{l}\mathrm{As}, \mathrm{Cr}, \mathrm{Co}, \mathrm{Hg} \\
\mathrm{Ni}\end{array}$ & $\begin{array}{l}\text { sample is digested by a mixture of concentrated } \\
\text { acids } \mathrm{HNO}_{3}, \mathrm{H}_{2} \mathrm{SO}_{4}, \mathrm{HClO}_{4}=10: 0.5: 2\end{array}$ & {$[50]$} \\
\hline $\begin{array}{l}\text { medicinal plant } \\
\text { species }\end{array}$ & $\begin{array}{l}\text { As, } \mathrm{Cd}, \mathrm{Co}, \mathrm{Cr} \\
\mathrm{Ni}, \mathrm{Pb}\end{array}$ & $\begin{array}{l}\text { plants were fried at } 105^{\circ} \mathrm{C} \text {, grounded, digested } \\
\text { with } \mathrm{HNO}_{3} \text { and } \mathrm{H}_{2} \mathrm{O}_{2} .\end{array}$ & {$[51]$} \\
\hline perennial plants & $\mathrm{As}, \mathrm{Cd}, \mathrm{Pb}$ & $\begin{array}{l}\text { a) } 1 \mathrm{~g} \text { plant sample is wet digested with } 16 \mathrm{~mL} \\
\text { mixture } \mathrm{HNO}_{3} \text { and } \mathrm{H}_{2} \mathrm{O}_{2}(6: 2) \text { on a hot plate; } \\
\text { b) } 1 \mathrm{~g} \text { plant sample is digested with } 6 \mathrm{~mL} \\
\mathrm{HNO}_{3} \text { and } 2 \mathrm{~mL} \mathrm{H}_{2} \mathrm{O}_{2}\end{array}$ & {$[52]$} \\
\hline
\end{tabular}

Beside the above mentioned techniques, literature studies mention X-ray fluorescence (XRF) and neutron activation analysis (NAA) which are able to simultaneously analyze many elements without destroying the sample by digestion.

Thus, Harris et al. evidenced that XRF is a suitable method for quantification of lead in vegetables [53]. In addition, by XRF was performed with good precision the determination of various heavy metals in medicinal plants and element distribution in rhizome, stalk, leaves and flowers [54].

World Health Organization recommended the NAA technique for analysis of plants, and since then, many studies reported the metals' levels from various medicinal plants [55]. Hence, according to Goncalves et al, metals' contents in different herbal medicinal plants assessed by NAA varied considerably from plant to plant, this behavior being attributed to the differences in botanical structure and to soil agrochemical characteristics [56]. By the same technique was drawn up a metallic profile for seven different herbs cultivated in medicinal crops in unpolluted regions from Romania [57].

In addition to nominated techniques, anodic stripping voltammetry (ASV) was reported as a valuable method for assessment of heavy metals in plant samples. ASV is characterized by high sensitivity, accuracy, precision and low costs. It is used for trace measurements of more than 20 elements (cadmium, lead, arsenic, mercury, etc) in different environmental samples [58]. Consequently, levels of $\mu \mathrm{g} \cdot \mathrm{L}^{-1}$ of lead, cadmium and zinc from medicinal herbs from Asia were ascertained by ASV and confirmed by ICP-OES [59]. In addition, investigation of the lead uptake 
by white lupin (Lupinus albus L.) performed by ASV evidenced that lead was accumulated in roots preventing leaves high level [60].

\section{CONCLUSIONS}

Heavy metals monitoring in vegetal products, especially in those destined for human consumption is a priority for food control, therefore, selection of the most appropriate method of analysis to obtain accurate results is a must.

For quantification of heavy metals in plants, literature studies present a large range of analytical techniques, the most used of them being addressed in this paper. Selection of one technique or other must be correlated with type of sample, the metal of interest and its' concentration in the sample, time of analysis, the financial possibilities of the laboratory. It is important to evaluate advantages and disadvantages of each method and to document before each analysis, moreover some available analysis protocols depicted in literature must be amended and adapted to the subjected sample to analysis.

\section{ACKNOWLEDGEMENTS}

This work is consistent with research directions and guidelines specified by Ministry of Agriculture and Rural Development in project ADER 1.4.4. Identification, evaluation, testing, development and validation of analysis methods of nutrients and contaminants from inputs usable in organic agriculture.

\section{REFERENCES}

[1] BRIFFA, J., SINAGRA, E., BLUNDELL, R., Heliyon, 6, 2020, e04691.

[2] JIAO, W., CHEN, W., CHANG, A., PAGE, A., Environ. Pollut., 168, 2012, p. 44.

[3] MORTVEDT, J.J., Fertil. Res., 43, 1996, p. 55.

[4] HOU, Q., YANG, Z., JI, J., CHEN, G., LI, J., XIA, X., ZHANG, M., YUAN, X., J. Geochem. Explor., 139, 2014, p. 68.

[5] FENG, W., GUO, Z., XIAO, X., PENG, C., SHI, L., RAN, H., XU, W., Ecotoxicol. Environ. Saf., 180, 2019, p. 160.

[6] MENTESE, S., YAYINTAS, O.T., BAS, B., IRKIN, L.C., YILMAZ, S., Environ. Manage., 67, 2021, p. 833.

[7] GUPTA, S., SATPATI, S., NAYEK, S., GARAI, D., Environ. Monit. Assess., 165, 2010, p. 169.

[8] WONG, M.K., TAN, P., WEE, Y.C., Biol. Trace Elem. Res., 36, 1993, p. 135.

[9] Commission Regulation (EC) No 1881/2006 of 19 Decembewr 2006 setting maximum levels for certain contaminants in foodstuffs.

[10] SINGH, S., PARIHAR, P., SINGH, R., SINGH, V.P., PRASAD, S.M., Front. Plant Sci., 6, 2016, 1143, https://doi.org/10.3389/fpls.2015.01143.

[11] ZHOU, H., YANG, W.T., ZHOU, X., LIU, L., GU, J.F., WANG, W.L., ZOU, J.L., TIAN, T., PENG, P.Q., LIAO, B.H., Int. J. Environ. Res. Public Health, 13, 2016, 289, https://doi.org/10.3390/ijerph13030289.

[12] SOURI, M.K., HATAMIAN, M., TESFAMARIAM, T., Chem. Biol. Technol. Agric., 6 , no. 25, 2019, https://doi.org/10.1186/s40538-019-0170-3.

[13] SINGH, S., ZACHARIAS, M., KALPANA, S., MISHRA, S., J. Environ. Chem. Ecotoxicol., 4, no. 4, 2012, p. 75.

[14] MANEA, D.N., IENCIU, A.A., STEF, R., SMULEAC, I.L., GERGEN, I.I., NICA, D.V., Int. J. Environ. Res. Public Health, 17, 2020, 5172, https://doi.org/10.3390/ijerph17145172. 
[15] WANG, Z., BAO, J., WANG, T., MORYANI, H.T., KANG, W., ZHENG, J., ZHAN, C., XIAO, W., Int. J. Environ. Res. Public Health, 18, 2021, 2617, https://doi.org/10.3390/ijerph18052617.

[16] GEBEYEHU, H.R., BAYISSA, L.D., PLoS ONE, 15, no. 1, 2020, e0227883, https://doi.org/10.1371/journal.pone.0227883.

[17] YANG, J., GUO H., MA, Y., WANG, L., WEI, D., HUA, L., J. Environ. Sci, 22, no. 8, 2010, p. 1246.

[18] GONG, L., QIU, D., YAO, X., YANG, G., Journal of Physics: Conference Series, 1549, 2020, https://doi.org/10.1088/1742-6596/1549/2/022008.

[19] PEQUERUl, A., PEREZ, C., MADERO, P., VAL, J., MONGE, E., Optimization of Plant Nutrition. Developments in Plant and Soil Sciences, Springer, Dordrecht, 1993, p. 3-6.

[20] UDDIN, A.B.M.H., KHALID, R.S., ALAAMA, M., ABDUALKADER, A., KASMURI, A., ABBAS, S.A., J. Anal. Sci. Technol., 6, 2016, https://doi.org/10.1186/s40543-016-0085-6.

[21] ABDELKAREEM, A.A.M., MAHMOUD, M.H.H., ALI, D.M.H.A., KHALID, M.A.A., ALOTAIBI, S.H., ELSHEIKH M.A.A., Sci. Technol. Public Policy, 2, no. 2, 2018, p. 26.

[22] HELALUDDIN, A.B.M., KHALIS, R.S., AlAAMA, M., ABBAS, S.A., Trop. J. Pharm. Res., 2016, 15 , no. 2, p. 427.

[23] BULSKA, E., RUSZCZYNSKA, A., Phys. Sci. Rev, 2017, https://doi.org/10.1515/psr-20178002.

[24] AMER, M., SABRY, B., MARREZ, D., HATHOUT, A., FOUZY, A., Toxicol. Rep., 6, 2019, p. 538.

[25] CIOBANU, C., SLENCU, B.G., CUCIUREANU, R., Studia Universitatis - Life Sciences Series, 23, no. 1, 2013, p. 33.

[26] BAgdatlioglu, N., NERGIZ, C., ERGOnUl, P.G., J. Consum. Prot. Food Saf., 5, 2010, p. 421.

[27] ARA, M.H., KHAN, A.R., UDDIN, N., DHAR, P.K., J. Hum. Environ. Health Promot., 4, no. 4, 2018, p. 144.

[28] HARMANESCU, M., ALDA, L.M., BORDEAN, D.M., GOGOASA, I., GERGEN, I., Chem. Cent. J., 5, 2011, 64, https://doi.org/10.1186/1752-153X-5-64.

[29] ALI, M.H., AL-QAHTANI, K.M., Egypt. J. Aquat. Res., 38, 2012, p. 31.

[30] QURESHI, A.S., HUSSAIN, M.I., ISMAIL, S., KHAN, Q.M., Chemosphere, 163, 2016, 5461.

[31] ALI, Z.N., ABDULKADIR, F.M., IMAM, M.M., Niger. J. Chem. Res., 17, 2012, p. 23.

[32] SAROJAM, P., Perkin Elmer Application Note.

[33] CHERFI, A., CHERFI, M., MAACHE-REZZOUG, Z., REZZOUG, S.A., Environ. Monit. Assess., 188, 2016, https://doi.org/10.1007/s10661-016-5140-7.

[34] GUERRA, F., TREVIZAM, A.R., MURAOKA, T., MARCANTE, N.C., CANNIATTIBRAZACA, S., Sci. Agric., 69, no. 1, 2012, p. 54.

[35] HUANG, Z., PAN, X.J., WU, P.G., HAN, J.L., CHEN, Q., Food Control, 36, 2014, p. 248.

[36] NEDElESCU, M., BAlAlAU, D., BACONI, D., JUlA, M., MORAR, D., GLIGOR, A., BALALAU, C., Farmacia, 63, no. 2, 2015, p. 296.

[37] WILSCHEFSKI, S., BAXTER, M., Clin. Biochem. Rev., 40, no. 3, 2019, p. 115.

[38] DANCA, A., Journal of Young Scientist, V, 2017, p. 27.

[39] AVCI, H., DEVECI, T., Ecotoxicol. Environ. Saf., 98, 2013, p. 283.

[40] GRUSZECKA-KOSOWSKA, A., Int. J. Environ. Res. Public Health, 16, 2019, 5096, https://doi.org/10.3390/jerph16245096. 
[41] MELAI, V., GIOVANNINI, A., CHIUMIENTO, F., BELlOCCI, M., MIGLIORATI, G., Int. J. Food Contam., 5, no. 8, 2018, https://doi.org/10.1186/s40550-018-0070-5.

[42] ESPOSITO, M., DE ROMA, A., CAVAllo, S., MIEDICO, O., CHIARAVAlle, E., SOPRANO, V., BALDI, L., GALlO, P., J. Food Compos. Anal., 84, 2019, https://doi.org/10.1016/j.jfca.2019.103302.

[43] LI, X., LI, Z., LIN, C.J., BI, X., LIU, J., FENG, X., ZHANG, H., CHEN, L., WU, T., Ecotoxicol. Environ. Saf., 161, 2018, p. 99.

[44] JIA, L.H., LIU, Y., LI, Y.Z., J. Pharm. Anal., 1, no. 2, 2011, p. 100.

[45] SARIC, E., BRATOVCIC, A., PAZIN, J., Technologica Acta, 10, no. 2, 2017, p. 25.

[46] MARIN, S., PARDO, O., SANCHEZ, A., SANCHIS, Y., VELEZl, D., DEVESAl, V., FONT, G., YUSAl V., Toxicol. Rep., 2018, p. 654.

[47] KOS, V., BUDIC, B., LOBNIK, F., ZUPAN, M., Fresenius J. Anal. Chem., 354, 1996, p. 648.

[48] MOHAMED, F., GUILlAUME, D., ABDUlWALI, N., AL-HADRAMI, K., MAQTARI, M., Heliyon, 6, 2020, e04908.

[49] LOPEZ, R., HALlAT, J., CASTRO, A., MIRAS, A., BURGOS, P., Biol. Agric. Hortic., 2019, https://doi.org/10.1080/01448765.2019.1590234.

[50] BHAT, R., KIRAN, K., ARUN, A.B., KARIM, A.A., Food Anal. Methods, 3, 2010, p. 181.

[51] STANOJKOVIC-SEBIC, A., MAKSIMOVIC, J., DINIC, Z., POSTIC, D., ILICIC, R., STANOJKOVIC, A., PIVIC, R., Nat. Prod. Commun., 12, no. 2, 2017, p. 185.

[52] SENILA, M., SENILA, L., ROMAN, C., J. Plant Dev., 18, 2011, p. 87.

[53] HARRIS, L., MCHENRY, L., GRUNDL, T. Food Chem., X, no. 1, 2019, https://doi.org/10.1016/j.fochx.2018.100001.

[54] CHUPARINA, E., AISUEVA, T., Environ. Chem. Lett., 9, 2011, p. 19.

[55] World Health Organization, Trace Elements in Human Nutrition and Health, Geneva, Switzerland, 1996. Available from: https://apps.who.int/iris/handle/10665/37931. [07.07.2021].

[56] FRANCISCONI, L., GONCALVES, R., DA SILVA, P., International Nuclear Atlantic Conference INAC 2013, Recife, PE, Brazil, November 24-29, 2013, https://inis.iaea.org/collection/NCLCollectionStore/_Public/45/084/45084468.pdf.

[57] HAIDU, D., PARKANYI, D., MOLDOVAN, R.I., SAVII, C., PANZARU, I., DEHELEAN, C., KURUNCZI, L., J. Anal. Methods Chem., 2017, https://doi.org/10.1155/2017/9748413.

[58] ABOllinO, O., GIACOMINO, A., MALANDRINO, M., Voltammetry/Stripping Voltammetry, Encyclopedia of Analytical Science (Third Edition), Academic Press, London, 2019, p. 238-257.

[59] INJANG, U., NOYROD, P., SIANGPROH, W., DUNGCHAI, W., MOTOMIZU, S., CHAILAPAKUL, O., Anal. Chim. Acta, 668, 2010, p. 54.

[60] NETO, M., DE VARENNES, A., Plant Soil, 154, 1993, p. 1.

Citation: Scaeteanu, G.V., Madjar, R.M., Mot, A., An overview of methods used for quantification of heavy metal contents in vegetal samples, Rom. J. Ecol. Environ. Chem., 2021, 3, no.2, pp. 7-15.

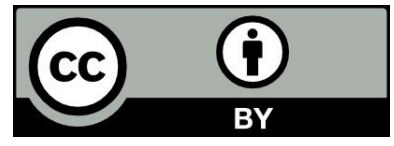

(C) 2021 by the authors. This article is an open access article distributed under the terms and conditions of the Creative Commons Attribution (CC BY) license (http://creativecommons.Org/licenses/by/4.0/). 